\title{
Contribution to the Anatomical Study of the Urinary System in Pigs
}

Fausto Arenas-Sarmiento, St. VMZ, Josimar Sneider Rincón-Uribe, St. $\mathrm{VMZ}_{2}$, Juan Camilo Álvarez-Peña, St. VMZ, Fabián Alejandro GómezTorres $^{*}$ VMZ, M.Sc ${ }_{1}$, Luz Stella Cortés-Machado, VMZ, Sp. ${ }_{1}$

, Animal Sciences Research Group (GRICA), School of Veterinary Medicine and Animal Husbandry ${ }_{2}$ Student, School of Veterinary Medicine and Animal Husbandry

Universidad Cooperativa de Colombia, Bucaramanga, Colombia

Recibido: 16 de febrero del 2015 Aprobado: 4 de mayo del 2015

* Autor de correspondencia: Fabián Alejandro Gómez-Torres. Facultad de Medicina Veterinaria y Zootecnia, Universidad Cooperativa de Colombia, Bucaramanga, Colombia. Calle 30A n. ${ }^{\circ}$ 33-51. Teléfono: (57) 7 6458500. Ext. 7095. Correo electrónico: fabian.gomez@campusucc.edu.co

Cómo citar este artículo: Arenas-Sarmiento F, Rincón-Uribe JS, Álvarez-Peña JC, Gómez-Torres FA, Cortés-Machado LS Contribution to the Anatomical Study of the Urinary System in Pigs. Spei Domus. 2015;11(22):17-24. doi: http://dx.doi. org/10.16925/sp.v11i22.1153

Abstract. Introduction: There are few studies and little research regarding the external and internal characterization of porcine kidney unlike other species. The purpose of this study was to establish the incidence of each anatomical pattern type of intrarenal vascular structures and excretory system of the pig, in addition to their external characterization. Materials and methods: The variables were analyzed on 60 renal blocks from animals destined for human consumption, which were ethically obtained from the meat processing plant Vijagual in Bucaramanga, Colombia, by injecting them with polyester resin. Results: The external morphometry for both kidneys determined a length of $120 \mathrm{~mm}$ and a width of $27.3 \mathrm{~mm}$. The renal arteries showed three different branching patterns (pattern I: $96.7 \%$; pattern II: $1.7 \%$; and pattern III: $1.6 \%$ ). A third subpattern (Ic) in group I was found in $9.4 \%$ of samples. The distribution of tributary veins exhibited pattern I (81\%) and pattern II (20\%). Pattern III was not present in any of the examined samples. The caliber of ureters averaged $6.9 \mathrm{~mm}$ and the width of renal pelvis was $12.2 \mathrm{~mm}$. The distribution patterns of calyces were divided into two groups (A: $30 \%$ and B: $70 \%$ ). Each pattern was subdivided into AI, AII, BI, and BII. Conclusions: The distribution patterns of renal structures found in this study are similar to those reported in previous studies, besides the contribution of an arterial pattern (Ic) evidenced by this research.

Keywords: renal artery, renal calyx, morphometry, ureter, renal vein. 


\section{Contribución al estudio anatómico del sistema urinario de los cerdos}

Resumen. Introducción: son pocos los estudios e investigaciones realizados sobre la caracterización externa e interna del riñón porcino a diferencia de otras especies. El propósito de este estudio fue establecer la incidencia que presenta cada tipo de patrón anatómico de las estructuras vasculares intrarrenales y del sistema de excreción del cerdo, además de su caracterización externa. Materiales y métodos: las variables fueron analizadas en 60 bloques renales provenientes de animales destinados para el consumo humano, lo cuales se obtuvieron éticamente de la planta de beneficio Vijagual de Bucaramanga, Colombia, mediante la inyección de estos con resina poliéster. Resultados: la morfometría externa para ambos riñones presentó una longitud de $120 \mathrm{~mm}$ y un ancho de $27,3 \mathrm{~mm}$. Las arterias renales presentaron tres tipos de patrones de bifurcación (patrón I: 96,7 \%, patrón II: 1,7 \% y patrón III: 1,6 \%). Un tercer subpatrón (Ic) del grupo i fue encontrado en el 9,4\% del total de muestras. La distribución de las venas tributarias presentó el patrón tipo I ( $81 \%)$ y el patrón II (20%). El patrón III no se evidenció en ninguna muestra examinada. El calibre de los uréteres fue en promedio de 6,9 mm y el ancho de la pelvis renal fue de 12,2 mm. Los patrones de distribución de los cálices se dividieron en dos grupos (А: $30 \%$ у в: 70 \%). Cada patrón presentó una subdivisión en AI, AII y BI, BII. Conclusiones: los patrones de distribución de las estructuras renales encontradas en este estudio son similares a las reportadas en estudios previos, además de la contribución de un patrón arterial (Ic) que se evidenció en esta investigación.

Palabras clave: arteria renal, cáliz renal, morfometría, uréter, vena renal.

\section{Contribuição para o estudo anatômico do sistema urinário dos porcos}

Resumo. Introdução: são poucas as pesquisas realizadas sobre a caracterização externa e interna do rim suíno à diferença de outras espécies. O propósito deste estudo foi estabelecer a incidência que apresenta cada tipo de padrão anatômico das estruturas vasculares intra-renais e do sistema de excreção do porco, além de sua caracterização externa. Materiais e métodos: as variáveis foram analisadas em 60 rins provenientes de animais destinados para o consumo humano, os quais foram obtidos eticamente da unidade de beneficiamento Vijagual de Bucaramanga (Colômbia). Mais tarde os rins foram injetados com resina poliéster. Resultados: a morfometria externa para ambos os rins apresemtaram uma longitude de $120 \mathrm{~mm}$ e uma largura de $27,3 \mathrm{~mm}$. As artérias renais apresentaram três tipos de padrões de bifurcação (padrão I: 96,7\%, padrão II: 1,7\% e padrão III: 1,6\%). Um terceiro subpadrão (Ic) do grupo I foi encontrado em 9,4\% do total de amostras. A distribuição das veias tributárias apresentou o padrão tipo I ( 81 \%) e o padrão II (20\%). O padrão III não foi evidenciado em nenhuma amostra examinada. O calibre dos ureteres foi em média de 6,9 mm e a largura da pelve renal foi de 12,2 $\mathrm{mm}$. Os padrões de distribuição dos cálices foram divididos em dois grupos (A: $30 \%$ e B: $70 \%$ ). Cada padrão apresentou uma subdivisão em AI, AII e BI, BII. Conclusões: os padrões de distribuição das estruturas renais encontradas neste estudo são semelhantes às relatadas em estudos anteriores, além da contribuição de um padrão arterial (Ic), que foi evidenciada nesta pesquisa.

Palavras-chave: artéria renal, cálice renal, morfometria, ureter, veia renal. 


\section{Introduction}

The traditional anatomy of pigs show arteries, veins, and renal calyces but, like humans, these structures also exhibit various intrarenal variations among individuals [1-7]. In humans various types of intrarenal structure patterns that have been clearly described in scientific literature are reported [8-14]. The incidence of these distribution patterns in pig kidneys has been described in previous studies, showing two artery patterns (I and II) $[1,12]$.

The incidence of patterns varies between 64 and $91 \%$ for the left and right kidneys respectively $[1,12$, 13]. In the vein patterns vary by $88.5 \%$ for the presence of two tributaries forming the renal vein and by $11.5 \%$ for the presence of three tributaries [14-17]. In the renal excretory system, patterns vary by $46 \%$ in the middle kidney area drained by smaller calyces dependent from groups of cranial or caudal calyces and by $60 \%$ in the group of independent calyces $[18,19]$.

This research aimed to determine the incidence shown by each anatomical pattern type of intrarenal vascular structures and excretory system of the pig.

\section{Materials and methods}

This cross-sectional study evaluated 60 renal blocks of animals intended for human consumption, which were ethically obtained from the meat processing plant Vijagual in Bucaramanga. Samples were obtained from commercial swine breeds destined for slaughter weighing 85 to $95 \mathrm{~kg}$. Once obtained, kidneys were placed in containers with water at room temperature for 6 hours to allow renal parenchyma exsanguinations and improve permeability of intrarenal structures. Each block of renal tissue was repaired with silk suture in the anterior end of the abdominal aorta and the posterior cava vein. The posterior ends of vessels collateral from organs other than the kidneys were ligated; also a repair with silk suture was applied to the distal segment of each ureter. Subsequently, a 14FR catheter was introduced through the aorta, cava vein, and repaired ureters to perfuse a semi synthetic polyester resin consisting of a mixture of $85 \%$ palatal GP40L and $15 \%$ styrene, with red, blue and yellow minerals for arteries, veins and the excretory system respectively [20]. Kidney specimens were immersed in a solution of $15 \% \mathrm{\kappa оH}$ for 10 days; full corrosion was achieved allowing to observe in detail the arterial, venous, and excretory systems and their collateral branch structures from their origin to their distal segments.

External kidney morphometry the gauge length of arterial structures, veins and their branches, and the entire collecting system were measured. Measurements of arterial and venous branches were performed using established patterns: pig renal arteries show two primary branching patterns ( $\mathrm{I}$ and $\mathrm{II}$ ). Pattern $\mathrm{I}$ is subdivided into patterns A and в (IA, IB) $[1,12,21,22]$.

According to the research conducted by Ballesteros et al. in humans, the venous drainage system is classified into three patterns: Type I, Type II and Type III. Pattern I, in turn, is subdivided into IA and IB patterns and Pattern II into IIa and IIb, which were assumed in this study due to lack of data on the species $[16,17]$.

Like the renal excretory system, at the discretion of Sampaio et al., two major anatomical variations are present: Type A and Type в. In Type A pattern, the middle area of the kidney is drained by a group of minor calyces dependent from the group of cranial and caudal calyces. This pattern is divided into $\mathrm{A} 1$ and A2 patterns $[18,19]$. In Type в pattern, the middle zone of the kidney is drained by minor calyces independent from the groups of cranial and caudal calyces. This pattern is subdivided into B1 and B2 [19].

The measurements of quantitative values were obtained using a digital caliper (Mitutoyo ${ }^{\circ}$ ), recording each value in an Excel table. Digital photographs of all samples were taken.

Continuous variables were analyzed using the t-test, whereas categorical variables were analyzed using Pearson's $\mathrm{x} 2$ test and Fisher's exact test. For the analysis of results, the statistical program "- Epi Info 3.5.4" was used. The level of significance used for this research was $(\mathrm{p}<0.05)$.

\section{Results}

The average length of kidneys examined was 120.9 $\mathrm{mm}$, sD 9.8; thickness, anterior and posterior width, and hilum width are shown in table 1.

It was demonstrated that $44.3 \%$ of renal arteries had a symmetrical origin from the abdominal aorta and $55.7 \%$ an asymmetric origin (figures 1 and 2). 
Table 1. Results of external morphometry of the right and left kidneys of pigs

\begin{tabular}{|c|c|c|c|c|c|c|c|c|c|c|}
\hline \multirow[t]{2}{*}{ Statistical measure } & \multicolumn{2}{|c|}{ Length (mm) } & \multicolumn{2}{|c|}{ Thickness (mm) } & \multicolumn{2}{|c|}{$\begin{array}{l}\text { Anterior width } \\
\qquad(\mathrm{mm})\end{array}$} & \multicolumn{2}{|c|}{$\begin{array}{l}\text { Posterior width } \\
(\mathrm{mm})\end{array}$} & \multicolumn{2}{|c|}{$\begin{array}{l}\text { Hilum width } \\
\qquad(\mathrm{mm})\end{array}$} \\
\hline & Right & Left & Right & Left & Right & Left & Right & Left & Right & Left \\
\hline Mean & 120.9 & 121.3 & 27.3 & 27.3 & 54.5 & 55.3 & 50.9 & 51.3 & 53.4 & 53.7 \\
\hline $\mathrm{SD}^{*}$ & 9.8 & 9.73 & 3.2 & 3.5 & 5.7 & 5.9 & 7.1 & 5.2 & 6.3 & 6.6 \\
\hline Maximum & 144.9 & 144.6 & 33.7 & 35.1 & 66.9 & 67.0 & 65.0 & 61.3 & 66.0 & 66.5 \\
\hline Minimum & 98.0 & 93.9 & 19.2 & 17.9 & 44.8 & 38.5 & 17.9 & 36.0 & 39.3 & 40.3 \\
\hline
\end{tabular}

Source: Compiled by the authors

The Type I distribution pattern (renal artery with two polar renal arteries supplying each pole) was observed in $96.7 \%$ of all specimens tested. Pattern IA describes two polar renal arteries that supply each pole and pattern Ів is a very short or nonexistent polar cranial artery and/or direct segmental branches of the renal artery. A final pattern (IC) with two polar renal arteries irrigating each pole and a medial artery was observed (table 2; figures 1 and 2).

Type II pattern, where a caudal polar branch emerges from the renal artery and two segmental

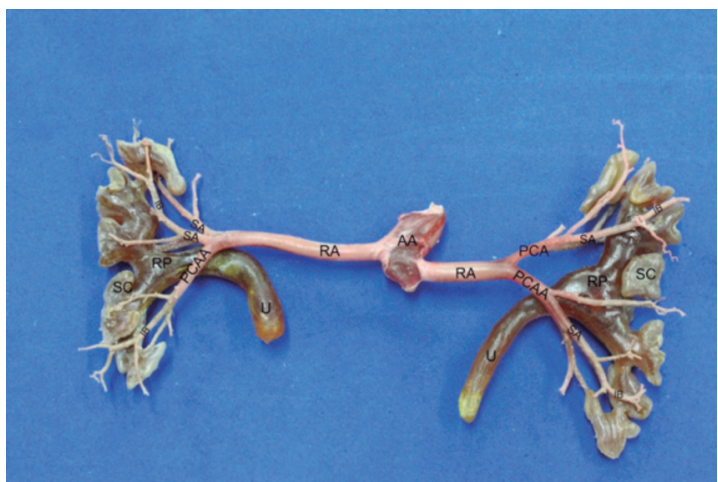

Figure 1. Ventral view of a renal block. On the left, a pattern where there is no cranial polar artery and two segmental arteries emerge directly from the renal artery is observed. On the right, a Type Ia is observed, where two polar arteries emerge from a renal artery. AA: Aorta artery. RA: Renal artery. PCA: Polar cranial artery. PCAA: Polar caudal artery. SA: Segmental arteries. IB: Interlobar branches. U: Ureter. RP: Renal pelvis. SC: Smaller calyces. Source: Compiled by the authors branches emerge directly from the renal artery to the cranial pole, appeared in $1.7 \%$ of right kidneys only. Type in pattern (several additional renal arteries directed towards the poles) was observed in $1.6 \%$ of our series (table 2 ). The number of interlobar branches ranged from 2-8, emerging from the anterior and posterior segmental branches of each kidney, where 2 interlobar branches occurred more frequently ( $42 \%$ of cases) followed by 3 in $31 \%, 4$ in $18 \%, 5$ in $5 \%, 6$ interlobar arteries in $3 \%$, and 7 and 8 in $1 \%$ of cases (figures 1 and 2).

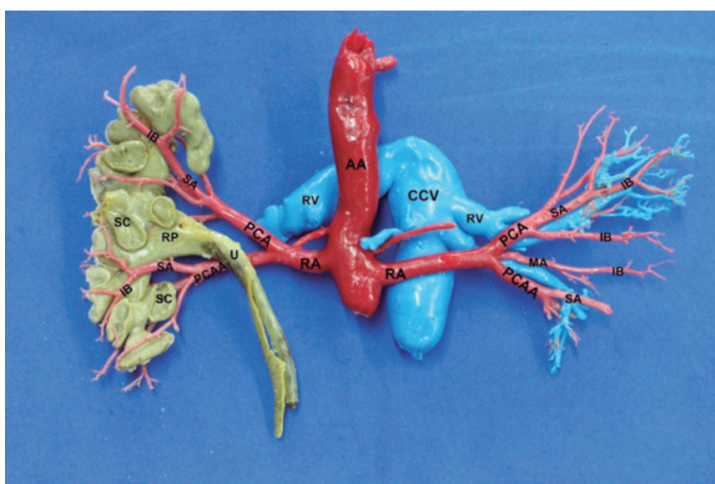

Figure 2. Dorsal view of a renal block. Asymmetric origin of the renal arteries. On the left, a Type Ia pattern is observed, where two polar arteries emerge from a renal artery. On the right, a Type Ic is observed, where there is an artery in the middle of the two polar arteries. AA: Aorta artery. RA: Renal artery. PCA: Polar cranial artery. PCAA: Polar caudal artery. MA: Middle artery. sA: Segmental arteries. IB: Interlobar branches. U: Ureter. RP: Renal pelvis. sc: Smaller calyces. CCv: Caudal cava vein. RV: Renal vein.

Source: Compiled by the authors 
Table 2. Pattern distribution of renal arteries of pigs

\begin{tabular}{|l|c|c|}
\hline \multicolumn{1}{|c|}{ Distribution pattern } & Right kidney & Left kidney \\
\hline Type I & $95.1 \%$ & $98.4 \%$ \\
\hline A & $65.5 \%$ & $66.7 \%$ \\
\hline B & $20.7 \%$ & $28.3 \%$ \\
\hline C & $13.8 \%$ & $5.0 \%$ \\
\hline Type II & $3.3 \%$ & $0.0 \%$ \\
\hline Type III & $1.6 \%$ & $1.6 \%$ \\
\hline
\end{tabular}

Source: Compiled by the authors

The position of the renal vein with respect to the renal artery was ventrally cranial in 24 right kidneys (39\%) and 31 left kidneys (51\%). The origin of the renal vein was extrahiliar in 37 right kidneys (61\%) and hilar in 32 left kidneys (52\%). The difference between the hilar and extrahiliar sources of the renal vein on both sides was not statistically significant $(\mathrm{p}=0.26$; figure 3$)$.

The pattern of a simple bilateral renal vein was observed in 50 kidneys (82\%), while single left pattern and double right pattern was present in 9 kidneys (15\%) followed by single right pattern and double left pattern on 2 analyzed kidneys (3\%).

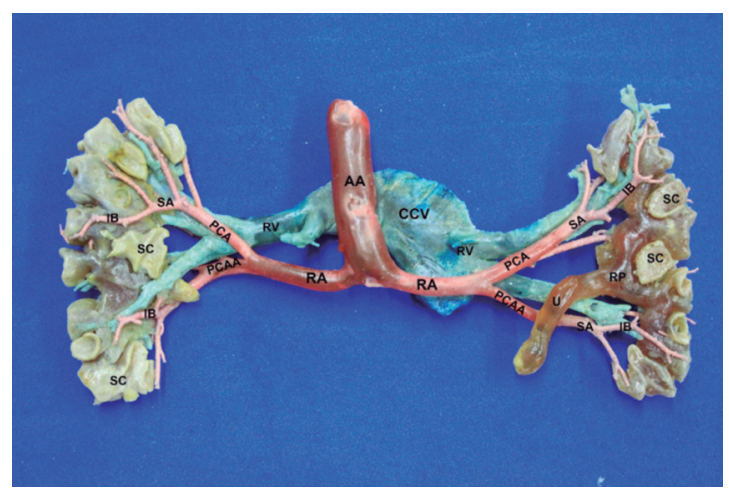

Figure 3. Dorsal view of a renal block. The position of a ventral cranial renal vein regarding the renal artery was observed bilaterally, as well as one origin extrahiliar on the right renal vein and one hilar on the left. AA: Aorta artery. RA: Renal artery. PCA: Polar cranial artery. PCAA: Polar caudal artery. SA: Segmental arteries. IB: Interlobar branches. U: Ureter. RP: Renal pelvis. SC: Smaller calyces. Ccv: Caudal cava vein. Rv: Renal vein.

Source: Compiled by the authors
The pattern of a double bilateral renal vein was not apparent in any case.

The Type I distribution pattern of tributary veins was observed in 50 right kidneys (82\%) and 48 left kidneys (79\%). Pattern IA (cranial and caudal tributaries) (Figure 4) appeared in 49 right kidneys (98\%) and 45 left kidneys (94\%) compared with Pattern гв (cranial and caudal tributaries plus a posterior tributary) present in one right kidney (2\%) and three left kidneys (6\%). The Type II pattern was evident in 11 right kidneys (18\%) and 13 left kidneys ( $21 \%$ ). The IIA pattern (more than two tributary veins- cranial, medial and caudal; figure 4) was present in 9 right kidneys (82\%) and 13 left kidneys $(100 \%)$. The IIB pattern was only seen in two kidneys (18\%) and Pattern III was not evident in any of the cases.

With respect to the renal excretory system, the caliber of ureters averaged $6.9 \mathrm{~mm}, \mathrm{sD} 1.7$ for the total number of cases. The width of renal pelvis, both on the right and left sides, showed a mean of $13.3 \mathrm{~mm}$, SD 3.8; the height of renal pelvis averaged $12.2 \mathrm{~mm}$, SD 4.1 (table 3). Regarding the Type a distribution pattern of calyces (middle of the kidney drained by smaller calyces dependent from a group of cranial or

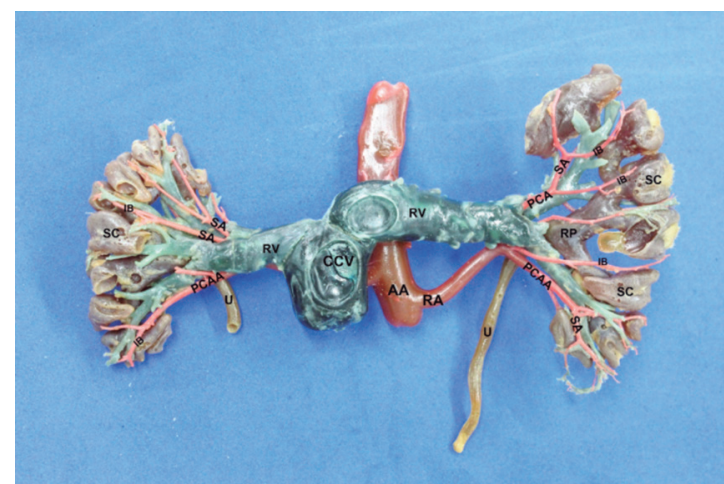

Figure 4. Ventral view of a renal block. On the left side, the IIa distribution pattern of tributaries of the renal vein is observed, where the renal vein is formed by cranial, caudal and middle tributaries. On the right side, the IA pattern is observed, where the renal vein is formed by cranial and caudal tributaries. AA: Aorta artery. RA: Renal artery. PCA: Polar cranial artery. PCAA: Polar caudal artery. SA: Segmental arteries. IB: Interlobar branches. U: Ureter. RP: Renal pelvis. sC: Smaller calyces. CCV: Caudal cava vein. RV: Renal vein.

Source: Compiled by the authors 
Table 3. Results of external morphometry of the right and left kidneys of the pig

\begin{tabular}{|l|c|c|c|c|c|c|}
\hline \multirow{2}{*}{ Statistical measure } & \multicolumn{3}{|c|}{ Left kidney } & \multicolumn{3}{c|}{ Right kidney } \\
\cline { 2 - 8 } & $\begin{array}{c}\text { Ureter } \\
\text { caliber (mm) }\end{array}$ & $\begin{array}{c}\text { Renal pelvis } \\
\text { width (mm) }\end{array}$ & $\begin{array}{c}\text { Renal pelvis } \\
\text { height (mm) }\end{array}$ & $\begin{array}{c}\text { Ureter } \\
\text { caliber (mm) }\end{array}$ & $\begin{array}{c}\text { Renal pelvis } \\
\text { width (mm) }\end{array}$ & $\begin{array}{c}\text { Renal pelvis } \\
\text { height (mm) }\end{array}$ \\
\hline Mean & 6.7 & 13.3 & 12.4 & 7.1 & 13.4 & 12.0 \\
\hline SD $^{*}$ & 1.6 & 3.7 & 4.3 & 1.9 & 4.0 & 4.0 \\
\hline Maximum & 11.3 & 25.7 & 27.8 & 12.8 & 27.6 & 26.1 \\
\hline Minimum & 4.0 & 6.2 & 6.2 & 3.6 & 6.3 & 5.4 \\
\hline${ }^{*}$ Standard Deviation & \multicolumn{3}{|r|}{} \\
\hline
\end{tabular}

Source: Compiled by the authors

caudal calyces; figure 5) was observed in 36 right and left kidneys for the total cases (30\%). The A1 pattern (long and thin cranial and caudal infundibula with dependent drainage) appeared in 29 total kidneys ( $81 \%$ on average). The pattern type A2 (short and wide cranial and caudal infundibula, with dependent drainage) was evidenced in 7 kidneys (20\%).

Type в pattern (middle of the kidney drained by minor calyces independent from a group of cranial or caudal calyces; figure 6) was observed in a total of 86 right and left kidneys (70\%). в1 and в2 patterns were determined similar to the $\mathrm{A} 1$ and $\mathrm{A} 2$ patterns, differing only in the direct entry of the calyces to the renal pelvis (table 4).

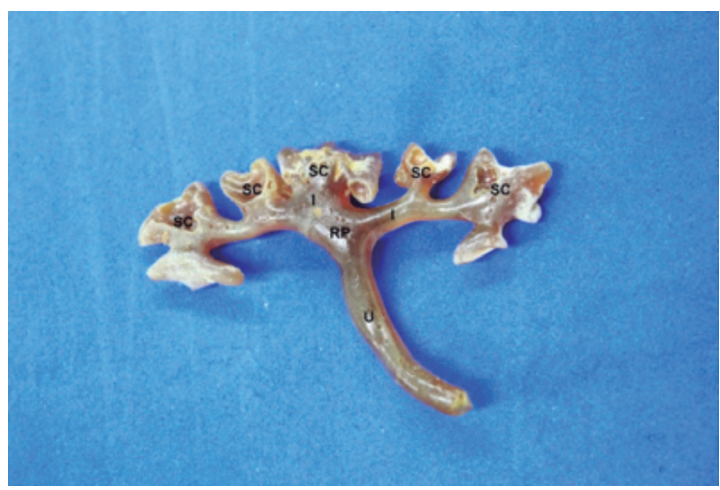

Figure 5. Ventral view of a left renal excretory system. Type A pattern is observed, where the middle of the kidney is drained by smaller calyces dependent from a group of cranial or caudal calyces. U: Ureter. RP: Renal pelvis. sc: Smaller calyces. I: Infundibulum.

Source: Compiled by the authors
Table 4. Distribution patterns of calyces

\begin{tabular}{|l|c|c|}
\hline Distribution Pattern & Right Kidney & Left Kidney \\
\hline Type A & $30.0 \%$ & $30.0 \%$ \\
\hline A1 & $78.0 \%$ & $83.0 \%$ \\
\hline A2 & $22.0 \%$ & $17.0 \%$ \\
\hline Type в & $70.0 \%$ & $70.0 \%$ \\
\hline в1 & $88.0 \%$ & $91.0 \%$ \\
\hline B2 & $12.0 \%$ & $9.0 \%$ \\
\hline
\end{tabular}

Source: Compiled by the authors

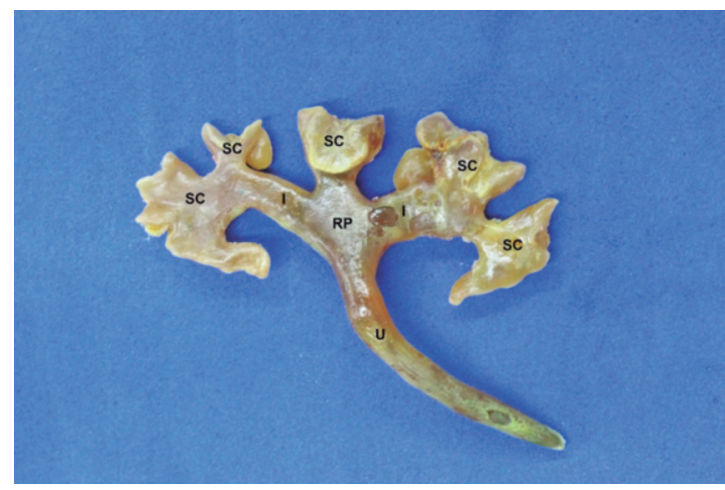

Figure 6. Dorsal view of right renal excretory system. Type в pattern, middle of the kidney drained by minor calyces independent from a group of cranial or caudal calyces. U: Ureter. RP: Renal pelvis. sc: Smaller calyces. I: Infundibulum.

Source: Compiled by the authors 


\section{Discussion}

The characteristics regarding external measurement of kidneys showed great similarity to the findings reported by Barcellos et al. in previous studies, which showed an average in the total samples with a length of $118 \mathrm{~mm}$, an anterior width of $56.4 \mathrm{~mm}$, a posterior width of $54 \mathrm{~mm}$, and a thickness of $28 \mathrm{~mm}$ [19]. These results are consistent with our findings, where there was not a marked difference with respect to previous reports, allowing to infer that there is no breed influence on the species when performing the external characterization of the kidney.

In previous reports we saw that the Type I distribution pattern of polar arteries is present in $91 \%$ of right kidneys and $64 \%$ of left kidneys, which agrees with our series $[1,12]$. Additionally, in our study a medial artery accompanying the two polar arteries was observed (Pattern IC). Our results corroborate the study of Evan et al., who reported that both polar caudal artery and polar cranial artery are subdivided into anterior and posterior segmental arteries [1]. These segmental arteries divide into interlobular branches irrigating the cortical area of each kidney [22].

The configuration of renal vein patterns in the porcine kidney exhibited great similarity to human kidneys according to the characteristics set out by Ballesteros et al. [17].

The bifurcation of the renal vein and caudal and cranial tributary veins (Type I), as evidenced in human beings, was highly present in the samples analyzed (80\%). Like in humans, the position of the renal vein with respect to the renal artery, was mostly cranial-ventral in the left kidneys (51\%) $[16,17]$.

Our findings regarding the renal excretory system are similar to previous research in human kidneys in which two groups are described regarding the drainage distribution pattern of calyces (A and $\mathrm{B})$. Pattern $\mathrm{A}$ in humans was present in $62 \%$ of cases unlike our results in which this pattern was evidenced in $30 \%$ of samples $[18,19]$. According to Barcellos et al., in comparison with human kidneys, there is no subdivision of pattern A (AI, AII) on pig kidneys [18]. However, in our research, it was determined that pattern A was subdivided into AI (81\%) and AII (20\%). In humans pattern B occurred in $38 \%$ of kidneys, while in pigs this pattern was evident in $60 \%$ of kidneys, as reported by Sampaio et al. [19]. Our results show that pattern B was present in $70 \%$ of kidneys. Unlike pattern A, pattern B in our study is consistent with the subdivision established by Barcellos et al. (1998), both in humans and pigs, where the average percentage of BI and BII was 21 and $16 \%$ in humans and 6 and $54 \%$ in pigs, while our findings were 90 and $10 \%$ respectively [17-19].

\section{Conclusions}

The incidence of arterial distribution patterns are similar to the results found in previous studies, except for the IC pattern that is evident in our research (medial artery accompanying the two polar arteries).

The expression of the distribution of renal calyces (AI and AII) was evident in our research unlike previous reports in which only the BI and BII patterns are reported.

These findings allow us to conclude the great anatomical similarity between porcine and human kidneys, which is key to establish bases and anatomical studies in both veterinary and human medicine models.

\section{References}

[1] Evan AP, Connors BA, Lingeman JE, Blomgren P, Willis LR. Branching patterns of the renal artery of the pig. Anat Rec. 1996;246:217-23.

[2] Paper O. Intrarenal arteries and their patterns in the Tuj sheep. Vet Med. 2004;49(2):57-60.

[3] Anjali W, Anshuman N, Jayshree D. Case Report: double renal arteries. 2012;22-4

[4] Vatsala AR, Ajay KT, Mavishettar GF. A study on branching pattern of renal arteries. 2014;2(1):270-2.

[5] Marques-Sampaio BPS, Pereira-Sampaio MA, Henry RW, Favorito LA, Sampaio FJB. Dog kidney: Anatomical relationships between intrarenal arteries and kidney collecting system. Anat Rec. 2007;290(May):1017-22.

[6] Horacek MJ, Earle AM, Gilmore JP. The renal vascular system of the monkey: a gross anatomical description. J Anat. 1987;153(17):123-37.

[7] Saldarriaga B, Pérez AF, Ballesteros LE. A direct anatomical study of additional renal arteries in a Colombian mestizo population. Folia Morphol. 2008;67(2):129-34.

[8] Raghavendra VP, Telkar A. Lower renal arterial segmental variations and its urosurgical. Int J Pharma Bio Sci. 2012;3(2):534-44. 
[9] Aristotle S, Sundarapandian, Christilda F. Anatomical Study of Variations in the Blood Supply of Kidneys. 2013;1555-7

[10] Antonetti C. Consideraciones anatómicas de las arterias polares renales. Rev la Soc Venez Ciencias Morfológicas. 2008;14(6).

[11] Saritha S, Jyothi N, Kumar M, Supriya G. Cadaveric study of accessory renal arteries and its surgical correlation. Int J Res Med Sci. 2013;1(1):19.

[12] Pereira-Sampaio MA, Favorito LA, Henry R, Barcellos FJ. Proportional analysis of pig kidney arterial segments: Differences from the human kidney. Int Braz J Urol. 2007;21(7):784-8.

[13] Saldarriaga B, Pinto SA, Ballesteros LE. Morphological expression of the renal artery: A direct anatomical study in a Colombian half-caste population. Int J Morphol. 2008;26(1):31-8.

[14] Khamanarong K, Prachaney P, Utraravichien A, TongUn T, Sripaoraya K. Anatomy of renal arterial supply. Clin Anat. 2004;17:334-6.

[15] Hauet T, Giraud S, Favreau F, Chatauret N, Thuillier $\mathrm{R}$, Maiga S. Contribution of large pig for renal ischemia-reperfusion and transplantation studies: The preclinical model. J Biomed Biotechnol. 2011;2011:14.

[16] Bagetti Filho HJ, Pereira-Sampaio MA, Favorito LA, Barcellos FJ. Pig Kidney: anatomical relationships between the renal venous arrangement and the kidney collecting system. Journal of Urology. 2008;179:1627-30.
[17] Ballesteros LE, Saldarriaga V, Ramirez LM. Morphologic evaluation of the renal veins: a study with autopsy material from Colombian subjects. Rom J Morphol Embryol. 2014;55(1):77-81.

[18] Barcellos FJ, Mandarim-De-Lacerda CA. Anatomic classification of the collecting system. J Endourol. 1988;2(3):247-51.

[19] Barcellos FJ, Pereira-Sampaio MA, Favorito L. The pig kidney as an endourologic model: anatomic contribution. J Endourol. 1998;12(1):45-50.

[20] Refojos M, Morley G, Nuñez M, Trindade de Veglia H. Repleción de vasos en órganos parenquimatosos de cerdo y bovinos con fines didácticos. Universidad Nacional del Nordeste. 2004.

[21] Verma P, Arora AK, Sharma P, Mahajan A. Variations in branching pattern of renal artery and arrangement of hilar structures in the left kidney: Clinical correlations, a case report. Ital J Anat Embryol. 2012;117:118-22.

[22] International Committee on Veterinary Gross Anatomical Nomenclature. Nómina Anatómica Veterinaria. 5th edition. Knoxville, Tennessee: Columbia, MO; 2012. 